DOI: $10.33741 / 0435-1991.41 .25$

\title{
СПЕЦІЛІЗОВАНА ВЧЕНА РАДА ДУ «ІНСТИТУТ ГЕМАТОЛОГІЇ ТА ТРАНСФУЗІОЛОГІЇ НАМН УКРАЇНИ»: СОРОК П’ЯТЬ РОКІВ РОБОТИ
}

\author{
Третяк Н. М., Павлюк Р. П. \\ ДУ «Інститут гематології та трансфузіологї НАМН України», \\ Київ, Україна
}

\begin{abstract}
Резюме
У статті наведена історична довідка про діяльність спеціалізованих вчених рад за радянських часів $i$ роки незалежності, детально проаналізована робота спеціалізованої вченої ради в ДУ «Інститут гематології та трансфузіології НАМН Украӥни». Проведений аналіз тематики як докторських, так $i$ кандидатських дисертаційних робіт, щзо були захищені за 45 років роботи спеціалізованої вченої ради, свідчить про розширення та поглиблення спектру наукових досліджень в галузі гематології та трансфузіології завдяки використанню нових діагностичних $i$ дослідницьких технологій таких як ичитогенетичні, молекулярногенетичні, імуноферментні, молекулярноімунологічні та інших, щуо в кінцевому підсумку сприяє утвердженню авторитету украӥнськоӥ науки.
\end{abstract}

Ключові слова: спеціалізована вчена рада, законодавча база, положення про діяльність, захист дисертацій, науковий внесок

Конфлікт інтересів: автори заявляють про відсутність конфлікту інтересів.

Фінансування: дослідження не мало спонсорської підтримки.

\section{SPECIALIZED SCIENTIFIC COUNCIL \\ OF THE INSTITUTE OF HEMATOLOGY AND TRANSFUSIOLOGY \\ OF NAMS OF UKRAINE: \\ FORTY-FIVE YEARS OF WORK}

\author{
Tretiak N. M., Pavliuk R. P. \\ SI «Institute of Haematology and Transfusiology of NAMS of Ukraine», \\ Kyiv, Ukraine
}

\begin{abstract}
The historical reference on the evolution of the organization of activity of specialized scientific councils during the Soviet times and years of independence is given, the work
\end{abstract}


of the specialized scientific council in SI «Institute of Hematology and Transfusiology of the National Academy of Medical Sciences of Ukraine» is analyzed in detail. The specialized scientific council of Hematology and Blood Transfusion was first established at the Kyiv Research Institute of Hematology and Blood Transfusion in 1977 and had the right to defend only $P h D$ theses in the medical field. The first chairman of the special council (1977-1988) was the director of the institute, MD. Ph. D., Professor Terekhov M. T., Scientific Secretary - Candidate of Medical Sciences Komisarenko V. G. In the following years, the council was headed by Dr. Med. Ph. D., Professor Perekhrestenko P. M. (1989-2013), Scientific Secretary - Candidate of biological SciencesGashchuk A. P., then Dr. Med. Ph. D., Professor Timchenko A. S. (2013-2018), starting from 2018 to the present-Dr. Med. Ph. D., Professor Tretyak N. M., Scientific Secretary since 2013 - Candidate of Medical Sciences Pavlyuk R. P. In 1993, the specialized council was authorized to defend doctoral dissertations in "hematology and blood transfusion» not only in the medical field, but in the biological field as well. Until now, biologists have defended on one-time defenses with the additional invitation of doctors of biological sciences. During the years of the special council's activity, after obtaining permission to defend doctoral dissertations, as well as dissertations in biological sciences, 136 dissertations were successfully defended, among them 82 - scientists, 54 general practitioners, about 5\% of them were graduate students. The analysis of dissertations, both doctoral and candidate, which were defended during the 45 years of the specialized scientific council, shows the expansion and deepening of the range of research in hematology and transfusiology through the use of new diagnostic and research technologies such as cytogenetic, molecular genetic, enzyme-linked immunosorbent assays, molecular immunological and others, which ultimately serves the benefit of man and contributes to the establishment of the authority of Ukrainian science.

Keywords: specialized scientific council, legislative base, regulations on activity, defense of dissertations, scientific contribution.

У Російській імперії вчені ступені присуджувалися безпосередньо в університетах. Після Жовтневого перевороту відсутність системи присудження наукових ступенів і звань та загальний дефіцит достатньо кваліфікованих і одночасно відданих політиці правлячої партії вчених, здатних адекватно оцінювати дисертаційні роботи, вимагали створення єдиного атестаційного органу, що й було зроблено. У 1932 році в СРСР була заснована Вища атестаційна комісія (ВАК). Фактично розпочавши роботу у 1934 році ВАК, за клопотанням рад вузів та наукових установ, затверджувала науковий ступінь доктора наук, вчені звання професора, доцента і старшого наукового співробітника, а також здійснювала контроль за роботою вчених рад з присудження наукових ступенів.

ВАК неодноразово змінювала підпорядкованість. Так, до 1974 року перебувала при структурах управління вищою школою, з 1975 року 
входила до Міністерства вищої освіти СРСР, очолювалася міністром і мала назву Вища атестаційна комісія при Раді Міністрів СРСР.

Так відбувалось аж до розпаду СРСР у 1991 році. [Прохоров А. М., главн. редактор. Большая советская энииклопедия. Москва: Советская энциклопедия; 1971. Том 5, Волков М. Н. Высшая аттестационная комиссия; с. 551].

ВАК України було утворено Указом Президента України від 25.02.1992 року № 100. ВАК України взяла за основу радянську модель спеціалізованих вчених рад, в той період використовувалась така ж система кодування і назв наукових спеціальностей, за якими захищались дисертації на здобуття наукового ступеня кандидата наук і доктора наук. У грудні 2010 року ВАК України було ліквідовано, а ії функції покладено на Атестаційну колегію Міністерства освіти і науки, молоді та спорту України. Таким чином, з 2011 року порядок створення і діяльність спеціалізованих вчених рад визначається Атестаційною колегією Міністерства освіти і науки України. У 2013 році Міністерство освіти і науки, молоді та спорту України було реорганізовано та створено два окремих відомства: Міністерство освіти і науки України і Міністерство молоді та спорту України. [Шемшученко Ю. С., відп. редактор. Юридична енциклопедія. Київ: Украӥнська енциклопедія ім. М. П. Бажана; 1998. Том 1, Карпенко Д. О., Хуторян Н. М. Атестаційна комісія; с. 160].

Формування спеціалізованих вчених рад відбувається з урахуванням існуючих наукових спеціальностей i, відповідно, за цими спеціальностями приймаються до захисту дисертації у вищих навчальних закладах третього і четвертого рівнів акредитації та інших установах, які проводять наукові, науково-технічні дослідження, а також мають високий рівень кадрового та матеріально-технічного забезпечення для підготовки наукових i науково-педагогічних кадрів вищої кваліфікації.

Діяльність спеціалізованих вчених рад регламентується Положенням, що затверджується наказом ВАК України.

Чинне Положення про спеціалізовану вчену раду затверджено наказом Міністерства освіти і науки, молоді та спорту України 14.09.2011 № 1059, a «Порядок присудження наукових ступенів» затверджений постановою Кабінету Міністрів України від 24.07.2013 р. за № 567.

На сьогодні, відповідно до Закону «Про вищу освіту», Національне агентство із забезпечення якості вищої освіти (НАЗЯВО) розробило Порядок присудження науково-освітнього ступеня доктора філософії на період до введення в дію Порядку присудження наукових ступенів і Положення про акредитацію спеціалізованих вчених рад. 
Для забезпечення захистів дисертацій здобувачами наукового ступеня кандидата наук, які розпочали підготовку до набрання чинності Порядку підготовки здобувачів вищої освіти ступеня доктора філософії та доктора наук у закладах вищої освіти (наукових установах) (Постанова Кабінету Міністрів України від 23 березня 2016 р. № 261), спеціалізовані вчені ради утворені відповідно до Положення про спеціалізовану вчену раду, що затверджене Наказом МОН від 14.09.2011 № 1059, продовжують свою діяльність відповідно до законодавства чинного на момент їх утворення.

Спеціалізована вчена рада в Київському НДІ гематології та переливання крові була вперше створена у 1977 році (Д 1169 за спеціальністю 14.00.29 - «гематологія і переливання крові»). До цього часу захисти дисертацій за спеціальністю «гематологія і переливання крові» відбувалися на засіданнях вчених рад в Центральному ордена Леніна Науково-дослідному інституті гематології і переливання крові у Москві, Ленінградському ордена Трудового Червоного Прапора Науково-дослідному інституті гематології і переливання крові у Ленінграді, Київському державному інституті удосконалення лікарів. Створена спеціалізована вчена рада мала право на захист лише кандидатських дисертацій. Директором інституту на той час був д. мед. н., професор Терехов М. Т. Він і став головою спецради (1977-1988 pр.), а вченим секретарем в той період була к. мед. н. Комісаренко В. Г.

Першими із співробітників інституту захистили дисертації і стали кандидатами медичних наук Волошина М. С., «Экспериментальное изучение натриевой соли сахарной кислоты как стабилизатора при консервировании крови» (науковий керівник д. мед. н., професор Караванов А. Г.), Дзюблик О. Ф. «Экспериментальное изучение амінокислотного препарата амикин для парентерального питания» (наукові керівники: д. мед. н., професор Караванов А. Г., д. мед. н. Федорова 3. П.), Дроздова В. Д. «Цитологические и цитохимические критерии в диагностике лимфогранулематоза у детей» (наукові керівники: к. мед. н., с. н. с. Бебешко В. Г., д. мед. н. Глузман Д. Ф.), Кірєєва С. С. «Нуклеазы и их ингибиторы в оценке течения острого лейкоза у детей» (наукові керівники: к. мед. н., с. н. с. Бебешко В. Г., к. мед. н. Шляховенко В. А.).

У 1989 році спеціалізовану вчену раду К.088.02.01 очолив новий директор інституту к. мед. н. Перехрестенко П. М.

Після перерви, зумовленої певними позанауковими обставинами, розпочався новий період діяльності спеціалізованої вченої ради. Згідно наказу ВАК України у 1993 році створена спеціалізована рада Д.01.40.01, що отримала повноваження проводити захисти докторських дисертацій 
за спеціальністю 14.00.29 - «гематологія і переливання крові» не лише в медичній галузі, а й у біологічній. До цього часу біологи захищались на разових захистах із додатковим запрошенням докторів біологічних наук.

Першими докторські дисертації в медичній галузі в новій раді захистили Суховій М. В. «Профілактика та лікування уражень опорно-рухового апарату у хворих на гемофілію» (наукові консультанти: Лауреат Державної премії України, Заслужений діяч науки України, д. мед. н., професор Скляренко Є. Т. і д. мед. н., професор Терехов М. Т.), Назарчук Л. В. «Принципи розробки антисиньогнійних і антипротейних препаратів донорської крові» (наукові консультанти: д. мед. н., професор Повстяний М. Ю. і д. мед. н., професор Федоровська О. О.), а в біологічній галузі - Мінченко Ж. М. «Генетичні системи крові людини при радіаційному опроміненні» (наукові консультанти: д. мед. н., професор Бебешко В. Г. і д. мед. н. Чумак А. А.). Усі дисертації написані українською мовою. Відповідними наказами робота спеціалізованої вченої ради подовжувалась на період до 01.09.2008 року (Наказ ВАК України від 4 липня 2005 року № 392), потім до 1 вересня 2011 року (Наказ ВАК України від 3 липня 2008 року № 935).

Згідно з Указом Президента України «Про оптимізацію системи центральних органів виконавчої влади» від 16 вересня 2011 року ВАК України було ліквідовано, а іiі функції покладені на Міністерство освіти і науки, молоді та спорту України.

Наказом Міністерства освіти і науки, молоді та спорту України від 29 березня 2012 року № 379 спеціалізованій вченій раді Д 26.612.01 було надано право на один рік проводити захисти дисертаційних робіт за спеціальністю 14.01.31 - «гематологія та трансфузіологія» (медичні науки).

В повному обсязі робота спеціалізованої вченої ради була поновлена через рік. Весь цей період (1998-2013 рр.) незмінним головою ради був д. мед. н., професор Перехрестенко П. М., вченим секретарем до 2005 року - к. мед. н., с. н. с. Комісаренко В. Г., потім - к. б. н., с. н. с. Гащук Г. П.

У 2013 році спеціалізовану вчену раду очолив новообраний директор інституту, д. мед. н., професор Тимченко А. С., заступником голови призначили д. мед. Н., професора Третяк Н. М., вченим секретарем к. мед. н., с. н. с. Павлюк Р. П., (наказ МОН України № 1021 від 07.10.2015 р.), у 2015 році діяльність спецради була подовжена (наказ МОН України № 1021 від 07.10.2015р.).

У 2018 році наказом Міністерства освіти і науки України від 04.04.2018 № 326 у ДУ «Інститут гематології та трансфузіології НАМН 
України» створюється нова спеціалізована вчена рада Д 26.612.01 з правом прийняття до розгляду та проведення захисту дисертацій на здобуття наукового ступеня доктора (кандидата) медичних та біологічних наук за спеціальністю 14.01.31 «гематологія та трансфузіологія» строком до 31 грудня 2020 року у складі 15 членів ради. Голова ради: Третяк Н. М., д. мед. н., професор; заступник голови: Горяінова Н. В., д. мед. н., с. н. с., в. о. директора ДУ «Інститут гематології та трансфузіології НАМН України»; вчений секретар: Павлюк Р. П., к. мед. н., с. н. с. Незважаючи на карантин через COVID-19, робота ради не припинялась, проводився розгляд і захист дисертацій з дотриманням усіх санітарних норм. Наказом МОН Україні від 22 липня 2020 р. № 946 роботу ради подовжили до 15 травня 2021 року, а потім - до 1 жовтня 2021 року (наказ від 23 квітня 2021 p. № 462).

За роки діяльності спецради після отримання дозволу на захист докторських дисертацій, а також дисертацій з біологічних наук, успішно захистились 136 дисертантів, серед них 82 - науковця, 54 - практичні лікарі, близько 5 \% 3 них були аспірантами.

У таблиці 1 представлений розподіл захищених дисертацій за роками.

Таблиця 1. Кількість захищених дисертацій за роками

\begin{tabular}{|l|c|c|c|c|}
\hline \multirow{2}{*}{\multicolumn{1}{|c|}{ Дисертації }} & \multicolumn{4}{|c|}{ Роки } \\
\cline { 2 - 5 } & $\mathbf{1 9 9 3 - 2 0 0 6}$ & $\mathbf{2 0 0 7 - 2 0 1 2}$ & $\mathbf{2 0 1 3 - 2 0 2 1}$ & Загалом \\
\hline Д. мед. н. & 11 & 6 & 4 & 21 \\
\hline Д. б. н. & 1 & 2 & 2 & 5 \\
\hline К. мед. н. & 43 & 26 & 22 & 91 \\
\hline К. б. н. & 13 & 3 & 3 & 19 \\
\hline
\end{tabular}

Як видно із даних, наведених у таблиці 2, вікова категорія здобувачів наукового ступеня доктора наук, в основному, представлена здобувачами старше 50-ти років, а кандидата наук - у межах 30-50 років.

Таблиця 2. Розподіл здобувачів за віком (2007-2021 рр.)

\begin{tabular}{|l|c|c|c|c|c|}
\hline \multirow{2}{*}{\multicolumn{1}{|c|}{ Дисертації }} & \multicolumn{5}{|c|}{ Вік } \\
\cline { 2 - 6 } & $<\mathbf{3 0}$ & $\mathbf{3 0 - 4 0}$ & $\mathbf{4 0 - 5 0}$ & $\mathbf{5 0 - 6 0}$ & $>\mathbf{6 0}$ \\
\hline Докторські & - & 1 & 4 & 10 & 1 \\
\hline Кандидатські & 4 & 26 & 16 & 8 & - \\
\hline
\end{tabular}


Переважна більшість дисертацій (41) була виконана в ДУ «Інститут гематології та трансфузіології НАМН України», 25 - в ДУ «Інститут патології крові та трансфузійної медицини НАМН України», 19 - ДУ «Національний науковий центр радіаційної медицини НАМН України», 5 - Національній медичній академії післядипломної освіти ім. П. Л. Шупика МО3 України. В різні роки захищались дисертанти з медичних університетів Полтави, Вінниці, Тернополя, обласних центрів крові Житомира, Донецька, Чернігова, Харкова, Києва, Івано-Франківська, обласних і міських лікарень, онкодиспансерів з Полтави, Черкас, Києва, Львова, Чернігова, Вінниці, Севастополя. Були дисертанти, які працювали в приватних структурах. Успішно захистив кандидатську дисертацію аспірант КМАПО ім. П. Л. Шупика, лікар-педіатр із Палестини.

За цей же час роботи спецради мали місце переатестації докторських дисертацій $(1995,1999)$, остання зумовлена набуттям Україною не залежності та зміною юридичних норм, одна кандидатська дисертація була відхилена на етапі захисту (1999).

Аналізуючи тематику дисертаційних робіт можна відзначити наступне.

Всі дисертації, що захищені в спеціалізованій вченій раді Д 26.612.01 за спеціальністю «гематологія та трансфузіологія», присвячені актуальним проблемам наукової галузі, а саме: питанням етіології, прогнозування, профілактики та лікування геморагічних ускладнень при легких формах коагулопатій і тромбоцитопатій; інфекційно-запальних ускладнень у хворих на гостру та хронічну лейкемію; вивченню механізмів порушень імунітету у хворих на мієлоїдну та лімфоїдну лейкемію; цитогенетичних аномалій при різних варіантах лейкемій; ролі еритропоетину в розвитку анемічного синдрому при гострій мієлоїдній лейкемії; створенню технології виробництва та обгрунтованню клінічного застосування плазмозамінних препаратів поліфункціональної дії; запропоновано інфузійно-трансфузійні заходи при спленектомії у хворих на ідіопатичну тромбоцитопенічну пурпуру та у хворих з анемічним синдромом при ендотоксикозі; розробленню методів корекції прихованих порушень метаболізму еритроцитів у донорів крові.

Наукові розробки дисертаційних робіт використовуються в практичній діяльності гематологічних відділень інститутів та в різних відділеннях обласних і міських клінік та лікарень, в центрах переливання крові. Результати досліджень внесені до реєстру галузевих нововведень і використовуються у педагогічному процесі кафедри гематології та трансфузіології Національного університету охорони здоров'я України імені П. Л. Шупика. Розроблені плазмозамінні препарати, зареєстровані та 
дозволені МО3 України до широкого медичного застосування, включені до клінічних протоколів надання медичної допомоги при невідкладних станах та різних захворюваннях, в т. ч. гематологічних.

Отже, проведений аналіз дисертаційних робіт, докторських і кандидатських, що були захищені за 45 років роботи спеціалізованої вченої ради, свідчить про розширення та поглиблення спектру наукових досліджень як в галузі гематології, так і трансфузіології завдяки використанню нових діагностичних і дослідницьких технологій таких як цитогенетичні, молекулярногенетичні, імуноферментні, молекулярномунологічні та інші, що в кінцевому підсумку сприяє утвердженню авторитету української науки.

Стаття надійшла 16.08.2021

Контакти: hematology@bigmir.net 